\title{
COLONY STRENGTH IN THE SPRING INSPECTION AND ITS IMPACT ON THE AMOUNT OF FORAGED POLLEN AT THE TIME OF RED CLOVER POLLINATION
}

\author{
G. Jevtić ${ }^{1^{*}}$, B. Anđelković ${ }^{1}$, Z. Lugić ${ }^{1}$, N. Nedić ${ }^{2}$, K. Matović ${ }^{3}$ \\ ${ }^{1}$ Institute for forage crops Kruševac, 37251 Globoder, Republic of Serbia \\ ${ }^{2}$ Faculty of Agriculture, Nemanjina 6, 11080, Belgrade-Zemun, Republic of Serbia \\ ${ }^{3}$ Institute of veterinary "Kraljevo", Žička br. 34, 36000 Kraljevo, Republic of Serbia \\ Corresponding author: goran.jevtic@ikbks.com \\ Original scientific paper
}

\begin{abstract}
In this study, the impact of honey bee colony strength in the spring inspection on the colony strength at the time of pollination, the amount of foraged pollen and on the colony strength in autumn was observed. The honey bee colonies were, after the spring inspection, divided into two groups, based on the amount of bees. The weak colonies, in spring inspection, had an average up to 4 frames occupied by bees and the strong colonies, in the spring inspection, had more than 6 frames occupied by bees. In addition to the amount of bees, the amount of brood and food supplies were assessed in the inspections. It was determined that the stronger colonies had more pollen foragers in all three year of observation. The quantity of foraged pollen, in addition to strength in the spring inspection, was influenced by year. In two years (first and third) more pollen and larger quantity of red clover pollen was collected by the strong colonies, while in the second year, more pollen and a large quantity of red clover pollen was collected by weak colonies. In the fall inspections was found that the strong colonies still had more bees and brood, more pollen and, also, more honey in relation to the weak colonies.
\end{abstract} pollen

Keywords: honey bee, red clover, colony strength, amount of foraged

\section{Introduction}

Unlike alfalfa, red clover is almost entirely cross-pollinated species (9798\%), and selfsterility is caused by gamete incompatibility. Flower morphology of this crop allows entomophile pollination, and the most significant pollinators are honey bee (Apis mellifera L.), bumble bees (Bombus spp.) solitary bees and others, (Taylor and Smith, 1979). A number of authors prefer bumblebees, but there are those that give primary role to honey bee (Palmer-Jones, 1967; Jevtić et al, 2010 
and others). Rao and Stephen (2009) have found that in the isolation cages with bumble bees $661 \mathrm{~kg} \mathrm{ha}^{-1}$ of red clover seed was obtained and $640 \mathrm{~kg} \mathrm{ha}^{-1}$ in cages with honey bees of red. In free fertilization without isolation, the yield was $1127 \mathrm{~kg}$ $\mathrm{ha}^{-1}$ seed.

Even that from spring inspection (late March) to early flowering of red clover (early July) three months pass, the strength of the colonies after the winter is the surest indicator of how they will behave in given year and what will be their role in pollination. Carnica overwinter in much weaker colonies than other races of honey bees. However, although it overwinters with significantly less bees than $A$. $m$. ligustica, carnica develops rapidly in spring and is very productive when it comes to honey foraging (Kulinčević 2006). In conditions of our country, very little was done in the issue of red clover pollination, so there are no results on the impact of honey bees in the pollination of this crop, let alone the necessary condition of bee colonies in order to perform this operation more successfully.

The aim of this study was to determine how much the colony strength established in the spring inspection has an impact on the development of colonies during the year and how much it influences the foraging activity of colonies in the summer at the time of pollination of forage crops, especially red clover.

\section{Material and methods}

In this study 20 honey bee colonies were used, hives were LR type with ten frames. Honey bees used in this experiment were of local ecotype of A. m. carnica Poll race. The trial lasted three years. Queen bees were 1-2 years old, and no colonies had queen bee older than 2 years. All included colonies were treated with same api-technical measures (all were feed the same, had the same stimulation of development). Colonies were treated against Varroa mite twice, in August (piretroids) and November (oxalic acid). Colonies wintered in the courtyard of the Institute for forage crops, and moved to the red clover field near Ćuprija. In the first year, colonies were located in the red clover field of $16 \mathrm{ha}$. In the second and third years, the colonies were at the same site, but the field was somewhat smaller (10 ha). In all three years the second cut was left for seeds production. Spring inspection was carried out in late March, and the colony strength and food supply were determined. The colony strength was determined visually through the area of frames occupied by bees $(1 / 10)$ and the area under the brood, by method from Rulebook on the performance testing in breeding livestock (S.G. R.S., 1996). Based on the strength determined in the spring inspection, colonies were divided into two groups. The first group (poor colonies) was comprised of colonies that had approximately 4 frames with bees and 1.5 frames with brood frames. In the second group (strong colonies) were ranked colonies that had an average of 6.5 frames with bees and 2.5 frames with brood. The amount of honey and pollen was determined visually, similar as two previous traits. Colonies were brought in the 
crop field in early July, when the clover started to flower (10-15\% flowers bloomed) and remained there for about three weeks. During red clover flowering, the counting of scout and forager bees was performed 5 times and pollen was taken using collectors. The number of bees was determined by counting scouts and foragers (bees with a load of pollen) which returned to the hive for 3 minutes. The total amount of pollen per colony was determined by using the pollen collectors to seize the pollen from forager bees which entered the hive. The obtained pollen was dried and measured in order to determine the total amount of collected pollen. After extracting the red clover pollen (based on color and microscopic analysis), its quantity was measured. Upon the end of red clover flowering, colonies were returned to the stationary apiary in Kruševac, where they wintered. The fall inspection was carried out in the first ten days of September, and the same parameters were observed by the same methodology that was used during the spring inspection.

\section{Results and discussion}

The colonies, in the spring inspection, had an average of 5.2 frames occupied with bees, weak had 3.9 frames, and strong had 6.6 (Table 1).

Table 1. Spring inspection of honey bee colonies, 2005-2007

\begin{tabular}{|c|c|c|c|c|}
\hline & Bees & Brood & Honey & Pollen \\
\hline \multicolumn{5}{|c|}{ Weak colonies } \\
\hline 2005. & 3.92 & 1.65 & 3.56 & 0.74 \\
\hline 2006. & 3.78 & 1.52 & 3.22 & 0.53 \\
\hline 2007. & 4.08 & 2.11 & 3.55 & 0.68 \\
\hline Average & 3.93 & 1.76 & 3.44 & 0.65 \\
\hline Stand. dev. & 0.60 & 0.44 & 0.75 & 0.26 \\
\hline $\mathrm{CV}$ & 15.62 & 27.60 & 21.79 & 39.04 \\
\hline \multicolumn{5}{|c|}{ Strong colonies } \\
\hline 2005. & 6.53 & 2.61 & 3.31 & 0.82 \\
\hline 2006. & 6.42 & 2.80 & 3.72 & 1.02 \\
\hline 2007. & 6.78 & 2.75 & 3.81 & 0.98 \\
\hline Average & 6.58 & 2.72 & 3.61 & 0.94 \\
\hline Stand. dev. & 0.80 & 0.54 & 1.37 & 0.43 \\
\hline $\mathrm{CV}$ & 12.43 & 20.37 & 39.71 & 48.88 \\
\hline Total average & 5.225 & 2.240 & 3.525 & 0.800 \\
\hline
\end{tabular}

The amount of brood varied more than amount of bees, especially in weaker colonies in the second year. In contrast to the colony strength, the food supply was much more uniform, especially regarding the amount of honey in the spring inspection. The colonies had an average of 3.5 frames of honey, and the differences between the groups were very small. In the first year weak colonies had 
more honey, and in the second and third years the strong colonies. There was a clear differentiation between the colonies when it comes to the amount of pollen. In all three years, strong colonies had more pollen in the spring inspection. In particular, the second year must be noted when the strong colonies had double the amount of pollen. In addition to the differences between the groups, the high intragroup variation for observed traits was determined. The variation coefficient (CV) for the amount of pollen had the highest value in relation to all observed traits and was high for the amount of pollen in weak colonies and the amount of honey in strong colonies (Table 1.).

The colony strength in the spring inspection depends on many factors, but primarily on climatic conditions, colony strength in wintering and measures taken in the spring. Nedić et al. (2011) found that the colonies of four selected lines had an average of 2.8 frames with bees, 3.9 frames with brood, 2.5 frames with honey and 0.5 frames with pollen in spring inspection. In the research of Jevtic et al. (2012) colonies in the spring inspection had an average of 5 frames with bees, 1.9 frames with brood, 3.6 frames with honey and 0.6 frames with pollen. Jevtic et al. (2004) concluded that the colony strength is affected by the amount of solid food that was feed to colonies during the winter. In addition, it was found that the strong colonies best wintered, had no loss during winter and in both observed years maintained superiority for the amount of bees and brood in relation to weak colonies (Jevtić et al., 2005).

When it comes to red clover pollination, there were high differences both in the colony strength and in the amount of foraged pollen (Graph 1.). The strong colonies, at the time of red clover pollination, had 13\% more scouts (251 scouts) than weak colonies (222 scouts). In addition, the strong colonies had $20.7 \%$ more foragers (74 in strong colonies, 61 in weak). During the study, the colonies foraged an average $94.9 \mathrm{~g}$ of pollen, strong colonies collected $102.2 \mathrm{~g}$ and weak $87.6 \mathrm{~g}$. The difference of $14.6 \mathrm{~g}$ in benefit of strong colonies shows that they foraged $16.7 \%$ more pollen. Strong colonies, in addition to the total amount of pollen, foraged larger quantity of red clover pollen in relation to weak colonies. Exception is in the second year when weak colonies foraged larger amount of both the total pollen $(61.46 \mathrm{~g})$ and red clover pollen (16.06 g) compared to the strong colonies (46.7 $\mathrm{g}$ of total pollen and $9.9 \mathrm{~g}$ of red clover pollen). For these two traits there is a large intra-group variation. 


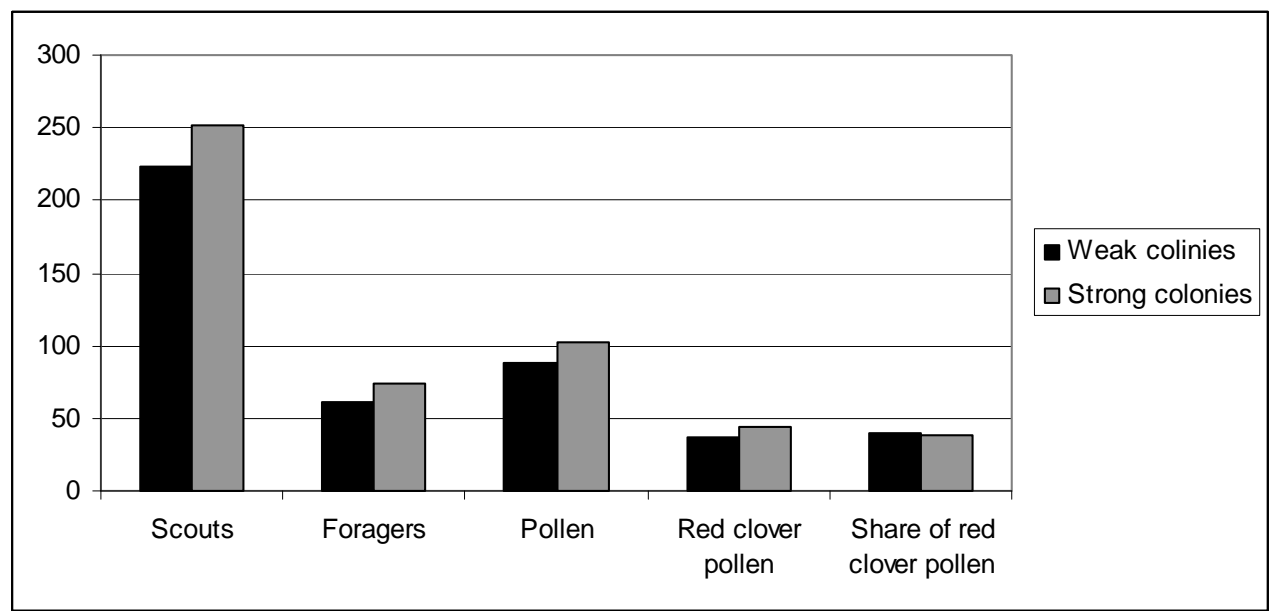

Graph 1. Average number of scouts and foragers, amount of foraged pollen, amount of foraged red clover pollen and share of red clover pollen 2005-2007

Maxfield-Taylor and Rao (2011) found, in two-year study, that honey bees, in both the early (July) and medium period (end of July, beginning of August), of the total amount of foraged pollen, foraged mostly pollen of red clover. In the late period (mid-August), in the first year, there was no red clover pollen, while in the second year red pollen was again dominant in the total amount of collected pollen $(92 \%)$.

Table 2. Number of scouts and foragers, amount of foraged pollen and amount of foraged red clover pollen 2005-2007

\begin{tabular}{|l|c|c|c|c|c|}
\hline & scouts & foragers & pollen & $\begin{array}{c}\text { Red clover } \\
\text { pollen }\end{array}$ & $\begin{array}{c}\text { Red clover } \\
\text { pollen share } \\
\text { (\%) }\end{array}$ \\
\hline \multicolumn{5}{|c|}{} & Weak colonies \\
\hline 2005. & 247.32 & 54.23 & 109.15 & 56.43 & 51.69 \\
\hline 2006. & 195.84 & 64.48 & 61.22 & 16.06 & 26.23 \\
\hline 2007 & 224.73 & 65.58 & 92.43 & 38.42 & 41.56 \\
\hline Average & 222.63 & 61.43 & 87.60 & 36.97 & 39.83 \\
\hline Stand. dev. & 42.80 & 19.06 & 48.59 & 26.59 & 15.18 \\
\hline CV & 19.57 & 26.21 & 49.24 & 73.19 & 46.48 \\
\hline \multicolumn{7}{|c|}{ Strong colonies } \\
\hline 2005. & 288.53 & 69.33 & 147.30 & 77.07 & 54.47 \\
\hline 2006. & 218.94 & 74.92 & 46.74 & 9.91 & 17.48 \\
\hline 2007. & 247.43 & 78.24 & 112.58 & 46.48 & 41.29 \\
\hline Average & 251.63 & 74.16 & 102.21 & 44.49 & 37.75 \\
\hline Stand. dev. & 72.76 & 9.32 & 52.31 & 34.69 & 19.77 \\
\hline CV & 33.07 & 14.84 & 61.95 & 98.87 & 63.06 \\
\hline Mean average & 237.130 & 67.797 & 94.903 & 40.730 & 38.790 \\
\hline
\end{tabular}


After completion of pollination, the colonies were prepared for the winter. There were still differences in the strength and food supplies in fall inspection between the colony groups that were determined in the spring inspection (Table 3 ). Strong colonies had more bees (9.3 frames) in fall inspections, in relation to medium strong colonies (7.5 frames). Brood area was identical in both groups. Strong colonies had 1.3 frames more of honey which is about $3 \mathrm{~kg}$ or $27.4 \%$ more. Strong colonies had more pollen. It is particularly interesting to note a high variation coefficient for this trait in both groups of colonies. This leads to the conclusion that in the group of strong colonies there were those who had had low supply of pollen, but also those in group of weak colonies with slightly more pollen. In the research of Nedić et al. (2011), colonies in fall inspection had approximately 5.3-6.1 frames with bees and average 5.14 frames with brood. In ten-year observation by Jevtić et al. (2012), it was found that the colonies, in fall, had an average of 6.1 frames with bees, 1.1 frames with brood, 4.4 frames with honey and 0.3 frames with pollen.

Table 3. Fall inspection of honey bee colonies, 2005-2007

\begin{tabular}{|c|c|c|c|c|}
\hline & Bees & Brood & Honey & Pollen \\
\hline \multicolumn{5}{|c|}{ Weak colonies } \\
\hline 2005. & 8.08 & 2.10 & 4.64 & 0.34 \\
\hline 2006. & 6.96 & 1.58 & 4.86 & 0.16 \\
\hline 2007. & 8.18 & 1.45 & 4.98 & 0.42 \\
\hline Average & 7.74 & 1.71 & 4.83 & 0.31 \\
\hline Stand. dev. & 1.42 & 0.96 & 1.48 & 0.24 \\
\hline $\mathrm{CV}$ & 18.46 & 49.76 & 31.41 & 86.70 \\
\hline \multicolumn{5}{|c|}{ Strong colonies } \\
\hline 2005. & 9.28 & 1.78 & 5.57 & 0.38 \\
\hline 2006. & 9.30 & 1.86 & 6.44 & 0.40 \\
\hline 2007. & 9.89 & 1.69 & 6.58 & 0.48 \\
\hline Average & 9.49 & 1.78 & 6.20 & 0.42 \\
\hline Stand. dev. & 2.54 & 1.07 & 1.48 & 0.27 \\
\hline $\mathrm{CV}$ & 27.34 & 59.47 & 25.26 & 70.28 \\
\hline Total average & 8.615 & 1.745 & 5.515 & 0.365 \\
\hline
\end{tabular}

\section{Conclusion}

After three-year observation, honey bee colonies in spring inspections had average of 5.2 frames with bees, 2.4 frames with brood, 3.5 frames with honey and 0.8 frames with pollen. Colonies that have been strong in the spring inspection showed the greater strength during red clover pollination due to higher number of scout bees and forager bees. Strong colonies were significantly more effective at the time of red clover pollination, as they collected for $16.8 \%$ more total pollen and red 
clover pollen for over $20.3 \%$ more. There is exception in the second year of observation when weak colonies foraged more total pollen and red clover pollen. Weak colonies foraged less red clover pollen compared to the strong colonies, but the proportion of red clover pollen in the total amount of collected pollen was slightly higher among them (39.8\%) than in strong colonies (37.7\%). In fall inspection strong colonies have maintained their superiority over the weak colonies because they had more bees and greater food supplies, while the amount of brood in this survey was quite uniform.

\title{
Acknowledgment
}

This research has been funded by Ministry of education and science of Republic of Serbia (Project TR31057).

\section{Snaga pčelinjih društva na prolećnom pregledu i njen uticaj na količinu sakupljanja polena u vreme oprašivanja crvene deteline}

\author{
G. Jevtić, B. Anđelković, Z. Lugić, N. Nedić, K. Matović
}

\section{Rezime}

U radu je praćeno kako, snaga društava utvrđena na prolećnom pregledu, utiče na snagu društava u vreme oprašivanja crvene deteline, na količinu sakupljenog polena, količinu polena crvene deteline i na snagu društva na jesenjem pregledu. Društva su nakon prolećnog pregleda, a na osnovu količine pčela, svrstana u dve grupe, od po 10 društava. Slaba društva su na prolećnom pregledu imala prosečno do 4 rama zaposednuta pčelama, a jaka društva su prosečno na prolećnom pregledu imala više od 6 ramova sa pčelama. Pored količine pčela na pregledima je praćena i količina legla, i zaliha hrane. Praćenje je trajalo tri godine, utvrđeno je da jaka društva imaju više izletnica $i$ više polenarica $u$ vreme oprašivanja crvene deteline $u$ sve tri godine posmatranja. Na količinu sakupljenog polena pored snage društva na prolećnom pregledu uticaj ima i godina. U dve godine (prvoj i trećoj) više polena ukupno i veću količinu polena crvene deteline sakupila su jaka društva, dok su u drugoj godini nešto više polena ukupno i veću količinu polena crvene deteline sakupila slaba drustva. $\mathrm{Na}$ jesenjem pregledu je ustanovljeno da su jaka društva i dalje imala veću snagu (više pčela i legla), više polena, ali i više meda u odnosu na slaba društva.

\section{References}

JEVTIĆ G., MLADENOVIĆ M., NEDIĆ N., DINIĆ B. (2004): Uticaj količine čvrste hrane na zimovanje pčelinjih društava. Biotechnology in Animal Husbandry, Vol.20, $\mathrm{N}^{\mathrm{o}}$ 5-6, str. 363-368. 
JEVTIĆ G., MLADENOVIĆ M., NEDIĆ N. (2005): The Influence of the Quantity of Honeybees and Honey Reserves on Wintering of Honeybee Colonies. $8^{\text {th }}$ International Symposium Modern Trends In Livestock Production Belgrade Zemun, Serbia and Montenegro 5 - 8th October. 315-321.

JEVTIĆ G., ANĐELKOVIĆ B., LUGIĆ Z., MLADENOVIĆ M., NEDIĆ N. (2010): The influence of the hive distance and the use of corn syrup on pollinator visits and red clover seed yield. Proceedings of the XII International Symposium on Forage Crops Of Republic of Serbia. Kruševac-Serbia 26-28 May, Book 2, 167172.

JEVTIĆ G., ANĐELKOVIĆ B., SOKOLOVIĆ D., ANĐELKOVIĆ S., MLADENOVIĆ M., NEDIĆ N., SIMEONOVA V. (2012): Impact of flowering time of major honey plants on honey bee colony development and honey yield in Rasina region. The first international symposium on animal science, Book II, Faculty of Agriculture, Institute for Zootechnique, Novembar 8-10 ${ }^{\text {th }}$, Belgrade, Serbia, 957-965

KULINČEVIĆ J. (2006): Pčelarstvo. Četvrto dopunjeno izdanje. Izd. Partenon Beograd. 1-322.

MAXFILD-TAYLORS., RAO S. (2011): Characterization of pollen loads from pollen traps placed in honey bee hives in red clover seed fields in the willamette valley http://cropandsoil.oregonstate.edu/seed-ext/sites/default/files/2-SR-11-06Maxfield-Taylor-Characterization-of-Pollen-Loads.pdf

NEDIĆ N., STOJANOVIĆ Z., JEVTIĆ G., PLAVŠA N., MATOVIĆ K. (2011): Variability of production characteristics of distinguished lines of bees in Western Serbia. Proceedings $3^{\text {rd }}$ International Congress "New Perspectives and Challenges of Sustainable Livestock Production" Belgrade, Republic of Serbia 5 - 7th October. 1379-1386.

NEDIĆ N., MALETIĆ R., MARKOVIĆ M., JEVTIĆ G., ANĐELKOVIĆ B., MATOVIĆ K. (2012): Morphological differentiation of honeybees (Apis mellifera) from Serbia. The first international symposium on animal science, Book II, Faculty of Agriculture, Institute for Zootechnique, Novembar 8-10 ${ }^{\text {th }}$, Belgrade, Serbia, 948-957.

PALMER-JONES (1967): Honey bees as pollinators of red clover. New Zeal. Jour. Agr. 114: 34-35.

RAO S., STEPHEN W. P. 2009. Bumble Bee Pollinators in Red Clover Seed Production. Crop Science, 49: 2207-2214.

SLUŽBENI GLASNIK R.S. br. 21, 16.05. (1996): Pravilnik o načinu ispitivanja svojstava priplodne stoke i o uslovima proizvodnje i transporta živine.

TAYLOR N.L., SMITH R.R. (1980): Red Clover Breeding and Genetics. Advances in Agronomy, 31, 125-154. 